\title{
An Inheritance that Cannot Be Stolen: Schooling, Kinship, and Personhood in Post-1945 Central Philippines
}

\author{
RESTO CRUZ \\ Social Anthropology, University of Edinburgh and Sociology, University of \\ Manchester
}

\section{PORTRAITS OF SUCCESS}

Eleven framed photographs line a wall of the Mahilways' house. Nine are of the siblings, though one brother is missing, and another is of a cousin. These images surround one of the siblings' deceased parents. In the place that I will call Santa Rosa, many families have similar displays, which often include framed degree certificates. These photographs in the Mahilways' house are unusually vivid. In them-black and white studio shots and the kinds of images shown in school yearbooks - the siblings and their cousin wear university gowns. The photo of the parents is in color and was taken on the occasion of one child's graduation.

The parents, Lolo Minong and Lola Ising, are considered exemplary by other old-timers. ${ }^{1}$ Like many of their generation, they had limited schooling and derived their livelihood from farming. They were among the first in the village to successfully send their children to college to pursue degrees in teaching, engineering, and nursing. ${ }^{2}$ Several of these children eventually migrated to

Acknowledgments: This essay draws from research supported by a Wadsworth International Fellowship from the Wenner-Gren Foundation and a Social Anthropology/Social and Political Science doctoral studentship from the University of Edinburgh. Writing was supported by the Evans Fund of the Department of Social Anthropology, Cambridge University. Earlier versions were presented at Leicester, Vienna, and St Andrews Universities. I thank the organizers and participants for stimulating discussions. I am indebted to Sophie Day for inspiring conversations, Janet Carsten and Jacob Copeman for giving extensive comments on this paper and the thesis from which it is drawn, and Magnus Course and Catherine Allerton for being fantastic examiners. Tom Chambers read my drafts patiently. Finally, the $\mathrm{CSSH}$ editors and anonymous reviewers gave immensely helpful suggestions.

I "Lola," "lolo," "tita," and "tito" mean "grandmother," "grandfather," "aunt," and "uncle," respectively.

2 I use "college" here to label higher education in general. 


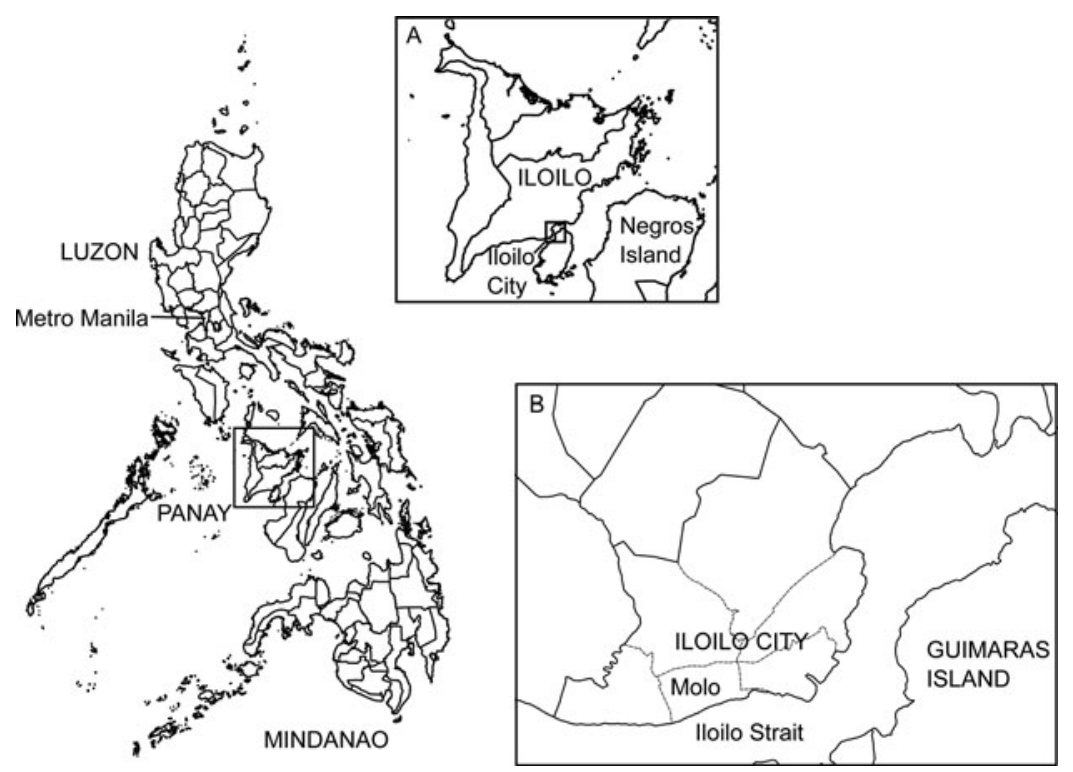

Map. 1. Map of the Philippines showing Panay Island (A) and Iloilo City (B). Based on original design by Bernardo Arellano III.

Manila, and later overseas. A majority of the grandchildren have also ventured abroad, mostly as healthcare professionals. The family's trajectory illustrates wider patterns of upward mobility and the emergence of the middle classes in the postwar Philippines (Bautista 2001; Pinches 1992).

Santa Rosa is a ward in southwest Iloilo City, the capital of Iloilo province. Located on Panay, an island in the Western Visayas region of the central Philippines (see map 1), Santa Rosa is densely populated, mostly by informal settlers along its riverine and coastal edges. As late as the 1970s, however, few people lived there and the land was devoted mostly to rice farming. Atop the village economy were a few sharecropping families (including the Mahilways) who remitted half of each year's harvest to their landlords. The Marcos dictatorship's land reform program in the 1970s allowed these families to purchase land over a fifteen-year period. Most residents, though, were farm workers employed by sharecroppers, while others fished the nearby river and strait. Some found employment downtown, mostly in manual work but also as salesclerks. Men, especially, labored on the waterfront, then the city's underbelly (McCoy 1982a: 346-48). Other people sold food and various items within the village and beyond. A few became drivers and servants in Iloilo and Manila.

Affluent families, mostly from Molo, a previously independent town, owned the land prior to the reform. These families were of Chinese mestizo 
provenance and derived their wealth initially from trade. ${ }^{3}$ In the late nineteenth century, several families migrated to neighboring Negros island to establish sugar plantations with the support of British capital (Aguilar 1998; McCoy 1982a). In Iloilo, they stored and shipped sugar and transacted with their creditors, maintained mansions, and lived lives of leisure and culture. Land and capital defined what it meant to be part of the local elite during this time, but so did forms of cultural capital, including schooling. Political office mattered also, especially during the American colonial period until immediately after the Second World War.

Extended ties to one of these families allowed the Mahilways to farm 17 hectares, almost a quarter of the village's land area. The husband of Lolo Minong's father's brother's daughter was a distant relative and lessee of the landowners, and he designated Lolo Minong as his sharecropper. In a neighboring town, the Mahilways farmed another 6 hectares whose owners employed Lolo Minong as overseer prior to his marriage. Despite all of this, family members during our conversations often portrayed themselves as having belonged to the landless. One story that I heard many times was how Lolo Minong used to exhort his children to study well since he had nothing to pass on to them. One of them recalled his words: "I've got neither money nor land to leave behind, only your schooling (edukasyon). It will be your inheritance. No one will be able to steal it."4

In what follows, I draw from an ethnographic and historical study of postwar social mobility in the central Philippines (Cruz 2017) to follow Lolo Minong's line of thinking. I examine schooling through the lives of the post-1945 generation. This generation was born between the late 1930s and early 1960s, their parents during the century's first two decades, and their own children between the late 1970s and early 1990s. I seek a capacious understanding of inheritance that goes beyond a unidirectional, top-down relationship between heirs and predecessors. I examine how inheritance generates ruptures and inequalities, and how it exceeds secular and economistic framings. Kinship and personhood, I argue, propelled postwar schooling, but both are markedly complex due to multiple and contending ideals, shifts in constructions of relatedness, broad historical transformations, and changes in personal circumstances through life. Schooling, in turn, generated contradictory consequences for persons and their relations. I mobilize a broad understanding of class that attends to lived experiences, including the changing meanings of class, how it is fundamentally relational and entails boundaries, and how it is constituted by ongoing processes. This approach has been fruitfully deployed

\footnotetext{
${ }^{3}$ Chinese mestizos are descended from Chinese immigrants who married local women. See Wickberg 1964.

${ }^{4}$ Following my interlocutors, I use edukasyon and schooling interchangeably. Schooling, however, is not the only form of education (Levinson and Holland 1996). Unless indicated otherwise, italicized terms are from Hiligaynon, the language spoken in Iloilo and the lingua franca in Western Visayas.
} 
by anthropologists studying the middle classes (e.g., Heiman, Liechty, and Freeman 2012). Such an understanding, as I will show, builds in part on the work of Bourdieu and his critics.

Between January 2014 and December 2015, I conducted sixteen months of ethnographic fieldwork in Santa Rosa. I worked principally with seven oldtimer families linked by intermarriages and friendships, although I also spoke with others. The people were predominantly professionals and included current and former migrants. Some were fulltime housewives/husbands who were unemployed or derived their livelihoods from the informal economy (e.g., food vending, laundering for neighbors). I elicited personal biographies and family histories, initially through unstructured interviews, but as I became more integrated into local networks, through conversations and participation in people's everyday lives. I also consulted local archives, mainly for material on land ownership and schooling. In this way, I was able to glean continuities and discontinuities between people's narratives, their lives and relationships, and wider historical trajectories.

I foreground here the Mahilways and their neighbors, placing them in their broader historical and social contexts. In doing so, I illustrate the wider consequences of kinship and personhood and show how historical events are enfolded into people's lives and relationships (Das 2007; McKinnon and Cannell 2013). Except for historical figures, I have changed people's names and altered or omitted details pertaining to disputes, so as to make identities less obvious. That said, I have made my discussion adhere as closely as possible to their accounts and experiences.

I will begin by elaborating how inheritance may be understood in relation to contemporary anthropological work on kinship, personhood, and schooling. I then situate descriptions of edukasyon as inheritance amid its increased value after the war, the post-1945 generation's dependence on their parents, and the acceptance of elite notions of inheritance. Postwar children are seen as completing and redeeming their parents and bestowing upon them status and prestige. Schooling is also acknowledged as an accomplishment of the children themselves, especially given the material difficulties and parental authority and expectations they face. Importantly, in achieving edukasyon children are also recognized as having had to suffer with and make sacrifices for their siblings. Failure to do so has generated fissures in relations, at times with ongoing repercussions. Schooling has likewise amplified class differences, even among kin. This process leads to moral judgments that can ultimately occlude the material and social underpinnings of schooling.

THE STAKES OF INHERITANCE

Recent anthropological scholarship has expanded discussions of inheritance beyond property to include not only everyday objects and biogenetic substances 
but also occupations, political dispositions, and other intangible transmissions. Many transmissions have both tangible and intangible aspects (Magee 2018). This more expansive approach allows investigation into which transfers are marked as inheritance, how, by and for whom, and with what consequences.

Anthropologists have highlighted how, in engaging with inheritances, people may draw from various ways of reckoning relatedness and at times contest established practices and norms (e.g., Kunreuther 2009). Inheritances can be experienced as overwhelming and lead to or exacerbate conflicts, and for this reason people may refuse them (Knight 2018; Lambek 2011). Similarly, inheritances may index loss, including efforts to compensate for them (Garcia 2014). Where kinship is reckoned bilaterally, including in the Philippines, such conflicts may be especially pronounced given the potential for disconnecting wider sets of kin (Edwards and Strathern 2000).

Contemporary accounts of inheritance vividly illustrate a broader turn toward examining how kinship is suffused with ambivalence and may be a site of enmity and ruptures as well as amity and solidarity (e.g., Carsten 2013; Das 2007; Peletz 2001). Kinship here is marked by complexities, hierarchies, and unevenness that are mediated by materials and their transfers (McKinnon 2017). Anthropologists have also portrayed inheritances and kinship as generative of broader inequalities, thereby critiquing entrenched views of kinship as distinct from, and subsumed by, the institutions of modernity (e.g., Bear 2014; McKinnon and Cannell 2013).

These accounts also reveal how inheritances braid complex temporalitiesthe legacies of past generations and broader histories, and how persons and relationships change over time. Inheritances may also be shaped by contests over the future, of persons and their kin and also of communities (Knight 2018). While often conceived intergenerationally, inheritances also implicate lateral relationships, as vividly illustrated by sibling feuds over parental bequests. Following Day (2012), examining inheritances pushes us to reconsider linear models of social reproduction wherein generations succeed one another in time and no scope is made for multiple temporalities.

Anthropologists have considered how inheritances are actively received. Drawing from Wittgenstein and his philosophical heirs, Das (1998; 2007 : 199-204) illuminates how the inheritance of one's culture may proceed akin to theft, and lead to the emergence of voice and the flourishing of personhood. From a different perspective, Ingold (2005) suggests that bequests enable persons and generations to move together in time, be enfolded in each other's lives, and co-create forms of life, though he stresses that correspondence between lives and generations is contingent and implies divergence. He likewise draws attention to how inheritances may have lives of their own. 
Anthropologists have not explicitly considered schooling in discussions of inheritance or, as Kipnis (2009) argues, of kinship and relatedness generally. An early if somewhat disconnected exception is Hall and Marcus's (1998) account of the shift in the United States to inter vivos transfers, particularly wealthy parents' allocations of resources for their children's schooling. Recently, Ingold (2018) has argued against seeing education as something transmitted passively, although he focuses more on knowledge than schooling per se. The omission of schooling from these discussions is glaring given the global expansion of schooling, especially since the Second World War, with broad consequences for childhood and social life (Anderson-Levitt 2005). Scholars interested in the continued relevance of inheritance and kinship need to examine schooling.

In fact, some of the conversations going on within the anthropology of schooling resonate with contemporary work on kinship and inheritance. One theme is how, in many contexts, schooling depends on resources and support from parents, siblings, and other kin, while it can also exert pressure on and transform kinship ties, particularly where upward mobility and migration are involved (e.g., Jeffrey 2010; Smith 2006). Schooling's sometimes contradictory consequences are highlighted (Froerer and Portisch 2012). Like kinship, schooling generates or reproduces personhood (Bryant 2001; Levinson and Holland 1996). These accounts reconsider, too, the limits of describing schooling as elite- or state-led (Bryant 2001). Children's (or siblings') schooling is often examined as an investment or strategy, or as embedded in cycles of exchange. Yet, though some writers have noted that schooling may be conceived as an inheritance, this angle has not been explored (Kunreuther 2009: 550; Johnson 1998: 226; for an exception, see Stambach 2000).

Part of the issue, it seems to me, is the tremendous influence of Bourdieu on studies of schooling within anthropology and cognate disciplines. Building especially on Bourdieu's earlier work (e.g., Bourdieu and Passeron 1977), this strand of analysis examines how inequalities are reproduced through schooling and highlights multiple forms of capital, their conversion into one another, and their long-term and intergenerational transmission. Important, too, are embodied dispositions that are accretions of capital and allow its further accumulation. Beyond the study of schooling, these insights have transformed the theorization of class. It is notable that, although Bourdieu's early writing (e.g., 1986) mentions the inheritance of capital, his discussion of this is rather limited and he devotes more attention to concepts such as investment.

In a later work that prefigures some of the contemporary discussions just outlined, Bourdieu (1999) does draw attention to "the contradictions of inheritance." Two points are most germane here. The first is that schooling may complicate transmission within families by acting as "a brutal and powerful reality principle which, by intensifying competition, is responsible for many failures 
and disappointments" (ibid.: 507). The second is that heirs enact identification/ disidentification, especially where families seek upward mobility. Referring to fathers and their children, Bourdieu highlights how successful inheritance in such a context implies "a murder of the father accomplished at the father's injunction, a going beyond the father that will preserve him and preserve as well his own 'project' of going beyond" (ibid.: 508).

Bourdieu proceeds to discuss how congruence between heirs and their ancestors cannot be assumed. Some heirs may reject their inheritance, while others may feel torn once they realize it, because they experience the resulting success as a betrayal of their origins. Sociologists have taken up these ideas to highlight the affective and ambivalent aspects of schooling and social mobility and question the uncritical celebration of upward mobility (e.g., Friedman 2016; Reay 2015). Others have questioned the image of the family as monolithic, which Bourdieu's work on reproduction may have unwittingly propagated (Atkinson 2013), notwithstanding his earlier work on Algeria (1977) and its influence on the practice turn in kinship studies.

Building on these developments, I will attend to how schooling may be underpinned by, and absorbed into, different and contending ideals and practices of relatedness and associated notions of personhood. I draw inspiration from Skeggs' (2004) critique of how Bourdieusian theory takes for granted a possessive and value-accumulating personhood, which does not necessarily reflect people's experiences, especially people at the margins of dominant regimes of value. Rather than maintaining an opposition between possessive and relational selves (by, for example, mapping them onto classes as Skeggs does), I will describe how schooling may coincide, and be imbued or in tension, with forms of personhood. Following the consideration of the complex temporalities sketched above, I examine kinship's and personhood's entanglements with schooling in relation to historical events, generational shifts and intergenerational exchanges, and movements through life.

My account also illustrates the importance in these matters of religion, broadly conceived. In this way, I speak to efforts to move past the picture that Bourdieusian theory paints of the world in which social existence always entails purpose and religion and morality have little analytical value (Hage 2014; Sayer 2005). I also contribute to the questioning of schooling's unproblematized association with secularism (Stambach 2006). Similarly, I am guided by scholars who have shown how relatedness among humans is "immodern": entangled with the religious-including religious institutions, ideas, practices, and spiritual beings - even where the state has supposedly supplanted religion and tradition within kinship (Das 2015: ch. 4; Lambek 2013). Religion, like kinship, is a site and source of complexity in that various ideals may coexist, be articulated, and permeate aspects of social life. 
THE VALUE OF SCHOOLING: COLONIAL LEGACIES, POSTWAR OPPORTUNITIES

As with the Hispanic Philippines more generally, schooling in nineteenth- and early twentieth-century Iloilo was largely an elite, male affair (Alzona 1932; Fox 1954). In Molo, schooling flourished amid its residents' prosperity, and institutions of learning catered mainly to the affluent, including the children of sugar plantation owners. Some Moloeños attended universities in Manila and Spain, and later they established colleges in Iloilo. ${ }^{5}$ With the advent of the American occupation in 1898 schooling became more accessible. A teacher-training school was established in Iloilo in 1902, and state-run schools were opened in the following years, as were private religious (mainly Catholic) institutions. ${ }^{6}$ Historical accounts of schooling in the Philippines during this period emphasize the role of colonial policy, including the United States' self-understanding as a "benevolent" empire (e.g., Alzona 1932; May 1976). Others have examined the role of ordinary American educators, but also that of a Protestant desire on the part of colonial officials to save Filipinos from what they deemed Catholic superstitions (Cannell 2005; Margold 1995).

In Molo and Iloilo, local non-elites mattered too. In 1905, the Baluarte Elementary School was established near Molo's coast through the efforts of Rosendo Mejica, a Moloeño accountant of modest origins. Although both of his parents were merchants and supported his schooling, financial difficulties forced him to work a series of jobs, including being a farmhand in a sugar hacienda in Negros, to save money for a course in accountancy (Sonza 1992). Mejica later organized residents of the coastal area and they petitioned the city government to establish the school and raised funds for a schoolhouse. The first erected in the American Philippines, the schoolhouse predated the 1907 Gabaldon Law that appropriated funds for schoolhouses throughout the colony. Older residents of Santa Rosa attended the Baluarte school, since no school was established in the village until the eve of the Japanese occupation, and until the 1960s that school offered no intermediate grades.

From 1913 to 1941, Mejica published Makinaugalingon (Self-Regarding). The longest-running and most widely read vernacular newspaper at that time, it was known as the "newspaper of the poor" due to the language that it used and its contents (McCoy 1982b: 184-85). Schooling was amply represented on its pages, with articles discussing the importance of schooling, examining the state

\footnotetext{
5 For instance, the Instituto de Molo's founders include Don Raymundo Melliza, who studied law in Manila, Barcelona, and Seville. A leader during the revolution against Spain, he became provincial governor during the American occupation (Manuel 1995: 335-36).

${ }^{6}$ See, for example, Makinaugalingon, 5 Sept. 1914: 3; 3 June 1915: 4; 15 Jan. 1924: 2.
} 
of teaching and learning in Iloilo, and highlighting the achievements of school graduates from the city and elsewhere in Western Visayas. ${ }^{7}$ Mejica also published the Almanake sang Makinaugalingon (1915-1952), an annual calendar that included essays and literary pieces on schooling and advertisements of educational institutions and professionals. During this time, too, a local form of theater (zarzuela) was popular among Iloilo's working classes, and some of the well-known productions revolved around schooling as a means to uplift the poor (ibid.).

These developments suggest that edukasyon was firmly in the imagination of Ilonggos, yet the fast-expanding world of schooling was not fully accessible to many Filipinos (Margold 1995; May 1976), including the Mahilway couple and their contemporaries. Lola Ising, who was born in 1919 to farmer parents in a town north of Iloilo City, only finished primary school at a state-run institution. Her father's early death forced her to leave school. Lolo Minong, born into a similar background a decade earlier, completed intermediate school. During the couple's childhood, I was told, it was unusual for parents to send their children beyond primary school, particularly if they were sharecroppers or, especially, farm workers. Few state schools had been established then and the agrarian economy remained viable. Fees ensured that private schools were inaccessible to most families.

Despite its limited accessibility, the state school system instilled schooling as a normative goal. It produced exemplars who achieved upward mobility through schooling and a cadre of Filipino pedagogues who bolstered schooling's value (Margold 1995: 386-90; see also Claudio 2015). It also, unwittingly, reinforced the devaluation of manual labor, which the Americans had blamed on their predecessors. The "Filipinization" of the colonial state's political offices and bureaucracy stimulated the formation of an educated and professional class. The state school system itself employed Filipino teachers. In Iloilo, a small but distinct professional, middle class began to emerge (Leichter 1975: 22-23). While the affluent continued to dominate the professions, a number of people from humbler origins made their way in, as Mejica had decades earlier. ${ }^{8}$

Schooling became more entrenched after the Second World War when the Mahilway siblings and their contemporaries came of age. When classes resumed, they attended the primary school in Santa Rosa, the intermediate school in Baluarte, and the newly established state high school in Molo. They eventually attended college, most of them at private Catholic institutions.

\footnotetext{
7 Some of its articles were addressed to youths and their parents, and some were translations of English articles that referenced American and European thinkers (e.g., Makinaugalingon, 22 Aug. 1922: 3; 24 July 1923: 1). On achievements of those with education see, for example, Makinaugalingon, 2 July 1919: 4; 7 Apr. 1920: 1; 10 Apr. 1920: 1.

${ }^{8}$ See also Locsin-Nava's (2001) biography of the novelist Ramon Muzones, a contemporary of the Mahilway couple.
} 
As elsewhere, in the Philippines there was an expansion of schooling as part of a postcolonial state-building project (Anderson 1988: 18-19; Anderson-Levitt 2005; Cortes 1980). However, many pupils did not complete their elementary schooling or proceed to secondary or higher education. ${ }^{9}$

Like today, state provision of higher education was limited. Most institutions demanded fees and places in the few state colleges were scarce. Given that most families had many children, getting them all a higher education was a challenge, especially when siblings overlapped at college. State scholarships and financial assistance helped a few Santa Rosa students, including some of the Mahilways. I was told that there was competition for scholarships and that applicants had to have earned a minimum school mark and pass an examination. Scholarships also formed part of patronage politics. In the 1950s, for example, local populist politicians established college scholarships for students from the lower classes that made up their support bases (Leichter 1975; LocsinNava 2001).

For the post-1945 generation, edukasyon took on importance in relation to the lack of or limited achievements of not just their parents but also their intermediate cohort (those born between the late 1920s and the 1930s), which suffered displacements resulting from the Japanese occupation (1942-1945). Many of the city's residents during the occupation had evacuated to the countryside and neighboring islands and moved constantly in search of food and to evade Japanese forces. Studies were disrupted, and some schools were made into garrisons or burnt to the ground. Schools reopened after 1945, but some displaced students felt they were now too old to join their new classmates and chose instead to work and, eventually, start their own families.

Iloilo's postbellum economy languished. Technological shifts meant that sugar haciendas in Negros no longer depended on the city for storage and transport, while protracted labor unrest further weakened ties between the city and the industry (McCoy 1982a). Although agriculture continued to matter, opportunities beckoned in the bureaucracy, the state school system, and emerging industries in Manila and other urban centers, but accessing these realms required qualifications. The old landed elite diversified, or shifted altogether, to industries, which in some cases meant moving to Manila (McCoy 2009; Pinches 1992). New Chinese immigrants dominated the local economy, while working and middle-class people took control of local politics (Leichter 1975; Omohundro 1981). This is why the postwar period is associated with the disappearance of Iloilo's landed elite.

To have no schooling or limited schooling during this time was to be incomplete; one lacked the knowledge and skills needed to navigate and

\footnotetext{
9 In 1925, for every hundred pupils entering grade one, only eighteen made it to grade six; in 1960 thirty-five made it, and in 1970 fifty-six, although only twenty-five of the latter completed secondary school and fewer than twelve finished college (Cortes 1980: 159).
} 
participate in a world that increasingly demanded literacy. It meant a life of toil as an agricultural, manual, and non-professional worker. These occupations meant hard work, economic precarity, and a lack of the prestige that a profession brought (see, for example, Tiryakian 1958). It also meant, as Pinches (1988) observed in 1980s Manila, vulnerability to degradation and shaming from one's economic superiors.

Edukasyon grew in value amid these histories of exclusion and displacement, and a world of emerging opportunities. By investing in their children's academic training, the Mahilway couple and likeminded parents joined other Ilonggos and Filipinos in accentuating schooling as key to gaining upward social mobility. In the 1930s, for example, peasants in Central Luzon began spending money on their children's schooling (Fegan 1978), and this pattern continues today (e.g., Aguilar et al. 2009; Martin 2015).

INHERITANCE AND HIERARCHY: CLASS INEQUALITIES AND TIES OF

F I L I A T I O N

I will now build on this history to explain how the postwar description of schooling as an inheritance suggests its status as a distinct investment. In addition to indicating schooling's increased value, such a description implies a moral comparison with class others, and also emulation of those in higher classes such as old landed elites. Likewise, it highlights how filiation was being elaborated during this period, and how dependent children were on their parents.

Villagers during my fieldwork, like Lolo Minong, often portrayed schooling as a new, and superior, sort of bequest. Underlying this claim is a contrast of education with land. To begin with, inheritance (panublion) conjures ideas of wealth, particularly that of the old landed elite. The local term for the wealthy, manggaranon, derives from manggad, which means property or valuables (Kaufmann 1900: 567). Although houses, images of saints, jewelry, and other valuables are all considered heritable, land is often proffered as the prime example of panublion and manggad.

It is said that schooling, unlike land, cannot cause family conflicts, and also unlike land, it cannot be partitioned and sold off. Villagers contrasted themselves with descendants of elite families, who they described as embroiled in disputes or as having sold off their possessions to finance extravagant lifestyles, in some cases without obtaining degrees. They attributed the postwar disappearance of Iloilo's elites to their having failed to preserve family patrimony and value schooling. Echoing Sayer's (2005) broader discussion of the moral significance of class, edukasyon and the distinctions and relations between classes are here freighted with moral connotations.

Schooling's supposed inalienability and superiority is linked to histories of dispossession in the region. Intriguingly, Lolo Minong's description of schooling as an inheritance that cannot be stolen evokes ideas put forward 
by David Barrows, the longest-serving Director of Education under the Americans. Barrows (1907) advocated universal primary schooling as a means to free peasants from landlords who, in his view, abused their lack of schooling to keep them indebted and tethered to the land. Others told me of elite families that possessed land that did not rightfully belong to them, which people blamed on the illiteracy of the older generations combined with the elites' knowledge of the law and connections to state officials. In Negros, land-grabbing occurred when elite Moloeños established haciendas (Aguilar 1998; Wolters 2010).

That said, the substitutability of schooling for land, and its superiority to it, is not absolute. In their conversations with me, people continued to associate manggaranon with possessing land, houses, and other valuables. "Oh, I'm not rich! I don't own land," said one woman from a humble background when her relatives teased her for her daughter having married a kinsman of a hacienda-owning Negrense family. A contemporary marker of successful upward mobility is ownership of property, especially in the city's new gated developments.

I would argue that the invocation of inheritance implies the acceptance of the inequality entailed by bequests. Although inheritance was practiced in preconquest times, it occurred within a relatively fluid social structure. Chiefs' heirs had to prove and build their own status, power, and wealth, and debt slaves and their descendants could rise socially through acts of prowess (Cannell 1999; Junker 1999; Scott 1994: 143-46). Land was neither privately owned nor alienable and heritable; it formed part of magical-material economies that linked chiefs and villagers in relations of debt and exchange (Aguilar 1998: 63-69). Chiefs were at the apex of local economies: unlike their subordinates, they were not only not indebted, but they dispensed debts.

Colonial innovations, including land titles (ibid.: 110-18; Wolters 2010), cemented inherited property's links with political-economic power. By the time the post-1945 generation came of age, upward mobility was conceived in terms of a new kind of bequest, but it was taken for granted that wealth, broadly defined, was to be passed on to some kin to the exclusion of others. Children's life-chances now depended on what their forebears gave them. The claim that schooling is a morally-superior inheritance is partly a misrecognition-in Bourdieu's (1977) sense - of the resources upon which upward mobility depends. A failure to acquire schooling is attributed either to parents having not bestowed the appropriate inheritance upon their children or to children failing to persevere.

The Mahilway siblings in their accounts often portrayed their parents as having had an active and dominant role; they urged them to study hard and think of their future, something Lola Ising affirmed in our conversations. "Persevere, for I want all of you to finish your studies," she recalled her husband telling their children. At other times, she spoke of how, when their children complained or were discouraged, she would tell them to persist, for "God's 
grace is everywhere." As did their contemporaries, the Mahilway siblings described themselves as having grown up at a time when children were constrained by their parents and other older kin, who often physically punished those who disobeyed them or misbehaved.

That the siblings completed their studies was a source of immense pride for the family, particularly Lola Ising. She was ninety-five when I first met her a few months before her death. She declared, "By God's mercy, I was able to raise them through farming. The expenses for their edukasyon also came from the farm." She explained that she had managed the family's landholdings because an illness prevented Lolo Minong from doing strenuous work. On another occasion she told me how she had received prizes-including a "Mother of the Year" award from local education authorities-for sending her children and those she had fostered to school. In one such instance she and other awardees were asked to narrate their life stories. Chuckling, she said: "Nobody there matched my achievements." In looking back, she considered her children's schooling as her own prize in life: "It was a difficult life, but the children finished their studies. That's my reward for all the hardship."

Part of the family's hardship, I was repeatedly told, stemmed from its large household size. Aside from the family, it included, at various points, the siblings' grandparents, an uncle, eleven cousins, and later three cousins once removed. Some farmhands also stayed with the family. The siblings often stressed the food expenses this entailed and that substantial portions of the family's share of harvests were consumed. They seldom ate meat, settling instead for vegetables and fish, and everyone had to eat at the same time so that food could be shared equally. Again, the Mahilways differed from most of their neighbors in having secure access to landholdings and seen from this angle their household's large size and associated expenses were markers of relative prosperity. Unlike some of their neighbors, the Mahilway siblings never mentioned experiencing hunger or having had to rummage for food. Moreover, for them, schooling expenses, and especially college fees, were less daunting and could be planned for. As I have hinted, the Mahilways' connections with landowners and position within the village hierarchy made them valuable allies of some of the politicians who dispensed college scholarships.

Ultimately, Lola Ising's claim that she was behind her children's successful schooling is predicated on the centrality of filiation. In Santa Rosa, I found, there is a considerable elaboration of and prominence given to parenthood and hierarchical parent-child ties. This situation contrasts with that documented among the Buid of Mindoro, where domination of children by their parents and other adults is actively minimized and avoided, something Gibson (1994) links to the Buid's history of resisting incorporation by lowlander Christians. Their lowland neighbors, just like the Ilonggos, grant importance to hierarchical relations, including those based on debt. 
Parents are likened to strings that tie siblings together, and their death is considered ominous for siblingship (see Cruz 2017: ch. 1). Children are seen to share substance with and take after their parents. Expressions like those documented in rural Panay remain current: "Character is in the blood," and "Whatever the tree, so is the fruit" (Jocano 1969: 16). As in maritime Southeast Asia generally (e.g., Carsten 1991; McKinley 1981; Schrauwers 1999), fosterage and adoption were common in the immediate postwar decades. A childless or economically better off person would take in the child of a sibling or cousin who had several children and was usually poorer. Likewise, uncles, aunts, and other kin would often help raise children, even those not fostered or adopted. However, though parenting is not limited to genitors, villagers stress that blood ties are ultimately weightier than others. Birth children are preferred because they are considered more likely to take care of their elderly parents.

Resonating with other lowland Christian areas of the Philippines, people in contemporary Santa Rosa consider children to owe their parents a debt of gratitude (utang nga kabalaslan) for the gift of life (see Hollnsteiner 1973; Kaut 1961). ${ }^{10}$ Parents are referred to collectively as ginikanan, "where one comes from." Schooling is considered part of children's debt to their parents, an expression of their economic dependence on them and of the cost of schooling. Debts of gratitude are considered unpayable, and so children are seen to be bound to their parents even after their parents die. Children are expected to obey and show respect to them and provide for them in their old age; failure to do these things brings opprobrium and a diminished stature as well as divine punishment (Jocano 1969: 102). This possibility suggests, following Rafael's (1993) discussion of the Tagalog correlate utang na loob, that indigenous notions of debt, as well as ties of filiation, have become linked to Catholic notions of sin and salvation. Here, as elsewhere, discourses of gratitude index inequalities within kinship as well as those resulting from broader social and economic transformations (Leinaweaver 2013).

Mothers, I found, occupy a privileged position in narratives of debt of gratitude. Many shared the view that the responsibility of looking after children's futures, including their schooling, is primarily lodged with mothers. Fathers, while expected to provide for their families, are also seen as having an innate proclivity to vice and irresponsibility (Blanc-Szanton 1990: 351). In the postwar decades, I was told, it was common for mothers, particularly those with no access to land (like the Mahilways' poorer neighbors), to take on multiple means of livelihood. These mothers were often described as having sacrificed considerably for their children. As the prizes Lola Ising

${ }^{10}$ Utang means debt, while kabalaslan is from balus, to return, pay back, respond. 
received suggest, the association between motherhood and children's schooling was recognized and reinforced by various institutions.

So long as children show interest, and resources permit, they are allowed to pursue schooling, a situation that prevailed after the war and during my fieldwork. Daughters are considered more likely and are expected to devote more time and effort to their studies than do their brothers, and therefore to be more likely to succeed. In part, this expectation builds on a widely shared Southeast Asian association of spatial mobility with men and domesticity with women (e.g., Carsten 1997; Errington 1990). Precolonial elites in Panay kept their unwed daughters inside the house to restrict the upward mobility of other families, a practice that was maintained in some upland areas (Blanc-Szanton 1990; Scott 1994; see also Cannell 1999). Catholic ideals introduced by the Spanish reinforced the association between femininity and domesticity, as did postwar appeals to "traditional" culture, especially among the upper and middle classes (Blanc-Szanton 1990). Boys, in contrast, have leeway to spend considerable amounts of time with their male friends (see Dumont 1993).

As I have alluded to in relation to fostering, parenthood for the older generations was often shared with lateral kin, a situation that exhibits how siblings and cousins resided close to one another and derived their livelihoods from a shared source. The prominence given to filiation, however, overshadowed lateral kinship ties. For instance, Lola Ising in her recollections downplayed the child-raising contributions of other family members, such as Lolo Minong's siblings and cousin, including their help with school-related expenses and everyday care. As parental figures, these kin expected to, and did receive care in old age from those they had looked after and supported. In other cases, the emphasis on filiation meant that lateral kin were discriminated against as parents prioritized their own children's schooling. Nieces and nephews, for example, were only supported until secondary school or were sent to vocational institutions, while their cousins were sent to college. ${ }^{11}$ Some of those supported by their aunts and uncles and other kin practically became servants to them. These nieces and nephews, often from poorer backgrounds, faced many difficulties and were usually disadvantaged in life.

SCHOOLING AS REDEMPTION: CHILDREN AND THEIR PARENTS' DELIVERANCE

Different and even contradictory ways of reckoning relatedness may coexist or succeed each other over time (Astuti 2000; Carsten 1997; Stafford 2000). In Santa Rosa, while people emphasize children's debts of gratitude to parents, they also describe postwar schooling in terms of children redeeming their

11 This preference persists today (Capuno and Javier 2015). 
parents. Here, what the parents are passing on is something they never had themselves. Rather than a unidirectional, top-down relationship between older and younger generations, redemption posits a two-way relationship between parents and children. Following Lambek (2013), redemption also accentuates schooling's, and kinship's, "immodernity": their meanings exceed those set by modern institutions and modes of existence and implicate religious and cosmological ideas.

When I told one of the Mahilway siblings about Lola Ising's claim of responsibility for the siblings' edukasyon, she agreed and emphasized that even if their parents had limited schooling they had made up for it through her and her siblings' academic achievements. She used the expression "ginbáwì sa kabataan," which may be glossed here as "they compensated through their children." I heard this expression every time villagers talked about uneducated parents who had endowed their children with edukasyon. Ilonggos in this way resemble others in the global south, and also immigrants in the global north, who see children's successful schooling as both a route to upward mobility and an appropriate response to parental hardships (e.g., Smith 2006).

Báwi carries meanings aside from "compensation." Kaufmann (1900: 113) defines it as "to redeem, reclaim, deliver, free, save, set at liberty, liberate, release." He includes examples pertaining to debt and mortgage, and redemption from sin and damnation. ${ }^{12}$ Báwi's (and edukasyon's) association with an absence of debt dovetails with debt's role in preconquest hierarchy and landlord-peasant ties, and children's indebtedness to their parents. But what about sin and damnation?

Like parental exhortations to persevere, depictions of schooling as báwì that I encountered during fieldwork evoke Catholic language and ideas, although I would not reduce them to Catholic influence. I noted earlier, following Cannell (2005), that American colonial schooling policy was entangled with a Protestant desire to save the colonized from Catholic beliefs. An earlier dictionary links báwi to acts of healing and deliverance performed by shamans (babaylan), including those addressing physical ailments and bewitchments (Méntrida 1841: 60). Until at least the 1970s and 1980s, especially in rural Panay, shamans performed a healing ritual, also called bawi, to retrieve a person's dungan (soul stuff, but also "double" or "together") from a malevolent spirit or witch (Magos 1992: 40-41; Ponteras 1980: 125). Cannell describes a similar notion of retrieving captured souls from powerful spirits among the Bicolanos of Southern Luzon (1999: 85-86).

\footnotetext{
12 For instance: "Ibáwì mo iníng pílak sa ímo dútà" (Use this money to reclaim your land); and "Ginbáwi kitá ni Hesukrísto sa salâ kag sa inpiérno" (Jesus Christ redeemed us from sin and hell) (Kauffman 1900: 113).
} 
Similar to other island Southeast Asian societies, precolonial and traditional Western Visayan cosmology posits humans as having varying levels (or "heights") of dungan, which, in addition to being a life force, enables persons to prevail upon and even dominate others (Aguilar 1998; Anderson 1990; Errington 1989; 1990; Magos 1992). In this cosmology, having a heightened dungan-becoming dunganon-is essential to becoming "men of prowess" (Wolters 1999). During my fieldwork, beliefs and practices surrounding dungan persisted, especially among older people. One woman in her late sixties, for example, described her deceased father as dunganon because of his ability to fight witches, including his second wife. Meanwhile, some of my classificatory cousins (born between the late 1970s and early 1990s) when they were infants underwent a ritual called batak dungan (lit. "pulling upward the dungan"), which enhances a person's dungan, thereby preventing sickliness or domination by others (Magos 1992: 49).

These semantic possibilities and histories suggest that, insofar as schooling is seen as a form of báwi, it involves the core of a person's being. The supposed inalienability of edukasyon makes sense not only in relation to the history of dispossession, but also to how schooling becomes, as it were, written into and comes to shape a person's being. In several Philippine settings, knowledge — of which, schooling may be considered a specific kind — is related to social adulthood, autonomy, and authority (e.g., Aguilar et al. 2009; Nydegger and Nydegger 1966; Rosaldo 1980). Parallels may also be drawn with the babaylan and other healers, who, in the Kinaray-a-speaking parts of Western Visayas, are known as ma-aram (knowledgeable or wise) (Magos 1992). Becoming knowledgeable is not just about gaining external recognition, but also entails profound transformations in one's personhood.

Just like edukasyon, shamanic forms of knowledge are deemed heritable (Cannell 1999: 125; Magos 1992: 59-61; Ponteras 1980: 274-75). However, rather than being considered akin to property or conceived in terms of debts of gratitude or redemption, shamanic knowledge is seen as a sulondon (lit. "something to be followed"). It is a practice that is bequeathed by ancestors and spirits and subsequently passed on intergenerationally; breaking the chain of transmission often results to illness or death in the family (Ponteras 1980: 177-78). With this in mind, we can see edukasyon as a continuation and transformation of prior cultural traditions, but also as a rupture given its association with colonialism, the state, and the market economy.

Báwi also suggests that the hierarchy implied by filiation is neither absolute nor unidirectional. Although villagers recognize that children owe their lives to their parents, they also consider that children give their forebears a sense of completion. So far as edukasyon is concerned, children are their parents' substitutes and transformations, earning them achievements that were previously difficult or impossible to accomplish; children's presents and futures are battlegrounds for reversing incurred losses and realizing once- 
foreclosed goals. Here it is useful to recall Rafael's (1993) discussion of the Tagalog utang na loob, where the loob (lit. "inside") does not exist prior to relations of exchange and is formed in and through the circulation of debt. Personhood thus results from what one gives to and receives from others, a concept long familiar to anthropologists studying a broad spectrum of cultures (Carsten 2004: ch. 4; Peebles 2010).

Children's roles are also presented in other ways. The meaning of parentchild ties and the configuration of hierarchy between them depend on where parents and their children are in their life courses. For instance, villagers expressed the ideas, common elsewhere in island Southeast Asia, that young children enliven houses, childless marriages are unfinished, and parents in their old age depend on their adult children (Aguilar et al. 2009; Allerton 2013: 54; Carsten 1997: ch. 2; Jocano 1969: 14-15). In addition, a person's achievements and standing are adjudged in later life, by both themselves and others, based on what has become of their children. This view is analogous to how, for the elderly Vezo of Madagascar, personhood emerges from being able to claim a multitude of descendants (Astuti 2000). We saw that Lola Ising thought of her children's successful schooling as her "reward" in life. People accepted, too, that children might end up different from their parents in adulthood, and that hierarchical parent-children relations are attenuated when children marry and shift their attentions and resources to their own families.

The idea of báwì at times evoked memories of pity, especially among those who had fewer resources in the past. Inday Gloria, a contemporary of the Mahilway siblings, described how her and her siblings' striving for schooling was prompted by seeing their widowed mother struggle to make ends meet by selling food at the city's waterfront: "We felt pity (luoy) for her, you see." They wanted to give her a better life, she said, by earning qualifications that would let them find secure and better-paying jobs. At nine years old, Inday Gloria would make the rounds of the surrounding villages to sell snacks before going to school. Her older sisters accepted laundry and ironing jobs and occasionally sold vegetables in the market. They gathered shellfish and small fish from the coast and ensured that dinner was ready when their mother returned home. Rather than simply being dominated by their parents, then, children took on active roles in the family. Previous accounts of pity in the Philippines (e.g., Cannell 1999) have highlighted how it enables the less powerful to secure recognition and concessions from their superiors and helps the latter to enact their ascendancy. Among those I worked with, pity enabled poor children to endure and overcome difficulties, for both their parents' and their own benefits.

Not all parents (or parental figures, generally) are deemed equally worthy of pity and redemption. Those whose children did poorly in school are open to accusations of bad parenting. This attitude is widely shared, even by those such 
as Inday Gloria who had fewer resources in the past. One evening I accompanied her on a debt-collection run. She had been selling meat on credit to her mostly poorer neighbors. Upon our return, she noted how most of those we had visited belonged to families that cared little about edukasyon: their parents had not sought to gain them academic credentials, and they now acted much the same toward their own children. Inday Gloria explained that this was why they were impoverished and likely to remain so. Moral boundaries concerning schooling, then, exist not only between the upwardly mobile and the old elite, but also between the former and their class subordinates.

These boundaries also apply among relatives. On another occasion, Inday Gloria intimated how her father's cousin and his wife ("uncle" and "aunt," respectively) took in her older brother Allan after her father's death. Evocative of a pattern observed elsewhere in Southeast Asia (Schrauwers 1999), Allan had to do housework in exchange for food, lodging, and school expenses. Their aunt, Inday Gloria said, was resentful and made sure that Allan did all the difficult tasks, and she disliked his siblings and was ungenerous whenever they visited him. Again, one of the corollaries of the emphasis on filiation is that parents prefer to support their own children's schooling. Allan, who was more academically inclined than his cousins, was eventually asked to leave, prompting Inday Gloria to work full-time as a maid to support his studies. Later, when their aunt was widowed and elderly, Inday Gloria cared for her until her death. Her children lived elsewhere and were not keen to look after her, and most of them gained no qualifications. Such was their aunt's punishment, remarked Inday Gloria, who visibly took pleasure in recounting this narrative since it indicated how she and her siblings succeeded against the odds, were morally superior to their aunt, and remained magnanimous and complied with generational hierarchy.

In some cases, children's unwillingness or inability to achieve academic success has led to strained relationships with their disappointed parents. Such strains are usually amplified when they must take up precarious and lowly work, or remain unemployed, and therefore acquire low social standing. Echoing Bourdieu's (1999) discussion of the "contradictions of inheritance," this dynamic is most pronounced where parents had substantial ambitions for their children. In families where siblings have done well in school, those who did not are omitted from accounts of achievement, or mentioned only in passing, or rehabilitated through justifications for their lack of academic success. To return to the scene with which I began this essay, the Mahilway sibling (brother) whose portrait was missing from the wall of photographs had a history of problematic schooling and vice, culminating in his early demise in the 1990s. Conspicuously absent from the family's visual display of successful schooling, he was presented in various narratives as having been innately intelligent and gregarious. His failure to achieve was attributed to a lack of interest in academics that is supposedly natural among men. 
PERSEVERANCE, SACRIFICE, AND AUTONOMY: SELVES AND SIBLINGS Having qualified the place of hierarchical parent-child ties, I now turn to how edukasyon is acknowledged as requiring heirs' active participation, both as individuals and as members of sibling sets.

One prominent way in which my interlocutors recalled personal striving was through accounts of walking to school. They resemble the elderly urban intellectuals of Jakarta interviewed by Mrázek (2010), in whose recollections walking to school during the Dutch colonial era loomed large. I worked with younger people of more modest backgrounds who grew up amid the global postwar expansion of schooling, yet the similarity with the Jakartan case hints at a predicament shared by the colonial and postcolonial educated classes. Despite material difficulties, both embraced schooling enthusiastically, especially the upwardly mobile. In both cases, too, schooling, though thoroughly embedded in companionship and solidarity, promised autonomy.

The village school excepted, my interlocutors walked from one to three miles each way. This experience had been more pronounced and difficult for older ones since the village school had offered no intermediate grades until the 1960s. Transportation in the earlier years was severely inadequate: roads were unpaved, and students had to walk across fields that became muddy and flooded during the monsoon season. Even when the transport situation had improved many continued to walk to save their allowance for school expenses. Moreover, they enjoyed walking, which allowed them to be with peers away from parents and other adults. For instance, one villager fondly recalled to me how she, along with relatives and friends, would stop every day at a bakery to buy toasted leftover bread that they would share on the way home.

Hunger, again, is a register of past hardship, especially among nonsharecropping families. Limited finances meant that students scrimped on food, since schools provided no meals. If resources allowed, they ate heavy meals at home, otherwise they made do with small snacks or nothing at all. Those attending secondary school and college would bring packed lunches, usually rice with fermented or dried fish, wrapped in banana leaves. Doing this frequently and regularly was, and continues to be, a marker of poverty, and I was told that students from Santa Rosa would eat their lunches in secluded areas of their school to avoid being teased by classmates.

Like in Inday Gloria's case discussed earlier, students supplemented or even replaced the allowance their parents gave them by engaging in productive activities. Again, older members of the post-1945 generation had done this more, partly due to their older siblings' quasi-parental responsibilities. Hence, the first three Mahilway siblings would every weekend rove through the nearby villages to sell vegetables they had grown. They also helped with other kinds of farm work. Like walking to school, farming had enjoyable 
and sometimes mischievous moments, such as gathering corn and legumes and cooking them for snacks without their parents' knowledge.

Like portrayals of schooling as báwì, accounts of personal striving recuperate agency for those whose aspirations were constrained during their youth. I am reminded of Mrs. Delgado, who was approaching seventy when I met her and whose father had been a coconut sap gatherer, her mother a vendor. She told me of how an uncle would often remark that since she would probably marry early and not finish her studies it was useless for her to go to school. While marriage could be a means of upward mobility, the pervasive sense among my interlocutors was that marriage lessened a child's responsibilities toward her parents and siblings. Mrs. Delgado's uncle went so far as to dissuade her parents, both of them unschooled, from supporting her, but this only motivated her to work harder: "I told myself that I have to study hard, that this is my chance. I really wanted to show them that I was worth it." This attitude paid off, since she subsequently garnered a scholarship for a teaching degree and later a master's course, and became a headteacher.

I found that schooling-related difficulties were fundamental to people's generational self-understanding. They set them apart from their elders, who were prevented by circumstances from pursuing edukasyon. They also set them apart from their juniors, who have had fewer obstacles to schooling and were sometimes described to me as lazy and spoiled. In emphasizing shared difficulties, some of the accounts I heard depicted state schools as mitigating the village hierarchy. Since all schoolchildren in those decades attended the same state-run institutions, the lines between sharecroppers and other families were blurred. Criticisms of those who did poorly in school thus foreground their lack of perseverance, yet, as I have emphasized, unequal access to land and social capital had decisive consequences, especially regarding postsecondary schooling.

Schooling brought the post-1945 generation more autonomy from older kin. Their earning wages was key to this process, but so was migration. Given Iloilo's postwar economic decline, there were limited jobs to be had in the city and job-seekers had to turn to other urban centers in the Visayas and beyond. In some cases, even though jobs might have been available locally, people still moved away to create distance between themselves and their elders. Such was the case with some of the Mahilway siblings who, after completing teaching degrees, moved to Negros. As one of them explained, "I didn't apply here in Iloilo. I didn't want to. I wanted to be independent. Here, you're overprotected." Equally important is that moving to bigger cities or overseas is, like schooling, a source of prestige and transforms personhood, as ethnographers of Southeast Asia have long noted (e.g., Errington 1990). Here, schooling and migration are not simply causally related, but also generate similar and converging outcomes (see Olwig and Valentin 2014). 
For some, to attain the autonomy afforded by schooling, and later by employment, meant refusing or contradicting the wishes of parents and other older kin. Some broke from occupational lineages that had become central to familial identity. For example, one man whose older male kin were known woodcarvers and makers of images of saints took a job as a seaman. His decision was initially met with resistance and skepticism, since at that time seafaring was considered unrespectable. By the time of my fieldwork, though, he had become a key figure in his family, no doubt enabled by his sizeable earnings as a captain of a transnational cargo ship. Tita Dolor, the first of the Mahilway siblings to become a teacher, recounted how her maternal grandmother, a manughilót (bone-setter and massage healer), wanted to bequeath to her the bottles of oil and other liniments that she had used to heal. Like shamanship, being a manughilót is passed on intergenerationally, and those who refuse to accept becoming one are said to risk dire consequences. Tita Dolor recalled telling her grandmother, “I don't want to become a manughilót. I'm already a professional."

The accounts that I heard portrayed overcoming school-related difficulties as a task carried out with and for siblings, but one unequally distributed among them. After they finished college and found jobs, older siblings from the post-1945 generation were expected to help younger ones complete their studies. Some had to delay courtship and marriage for this reason. The youngest often had an advantage since by the time they went to college there was often less financial pressure on their families. They could rely on older siblings and even enroll in more expensive degree programs. I encountered instances where older siblings took fulltime work to help younger siblings with their expenses due to a combination of hardships and unanticipated shifts in regulations (e.g., elementary teaching became a four-year rather than two-year degree program).

Those who helped their siblings with their schooling, especially when their own educational and marital aspirations were delayed or foregone, are often described as having "sacrificed" their future. As with parents, the "other side" (Mayblin and Course 2013) of their sacrifice is that they will be cared for in their later years by the siblings who benefitted or those siblings' children. Here, people in Santa Rosa draw on a language of sacrifice that is widely shared in the Philippines; although it has Catholic roots, it has been appropriated across historical moments and has permeated kinship relations (Cannell 1999).

The significance of siblingship in this context fits a broader pattern of kinship in island Southeast Asia (Aguilar et al. 2009; Cannell 1999; Carsten 1997; Errington 1989; 1990; McKinley 1981). In Western Visayas, personhood's relationality involves not only filiation but also siblingship. The notion of dungan, discussed earlier in relation to redemption, suggests that Western Visayans traditionally viewed persons as always already within 
siblingship. As a person's "double" and an entity that one is always "together" with, the dungan may be thought of as a sibling, akin to the "birth siblings" and "body siblings" documented elsewhere in the region (e.g., Allerton 2013: 3940; Carsten 1995; 1997: 83-84). While siblingship has a long and privileged status in analyses of Southeast Asian kinship, anthropologists have increasingly examined the importance of sibling ties elsewhere in the world, including in relation to schooling (e.g., Kajanus 2015; Obendiek 2013).

Although the expectation of sibling solidarity applies to all, brothers are more likely to get away with non-compliance because, again, men are perceived as generally less reliable than women. Women are more likely to face pressure to support their siblings and, if needed, delay or forego marriage. Moreover, once married, and to the extent that they are responsible, men are likely to focus primarily on their own families, while married women are expected to also extend support to their siblings and parents when possible.

Those who marry without helping at least one sibling, especially if they marry against their parents' wishes, elicit comments (usually in hushed voices) that they are acting like a glutton (dalók). The use of the idiom of gluttony here is significant given the centrality of hunger and food sharing in people's experiences and narratives of schooling. Accounts suggest that in the postwar years objections to a sibling's or child's marriage were strongest when their spouse came from a poorer background or showed little promise of upward mobility. Such objections cast a long shadow on both parent-child relations and ties of siblingship, sometimes reaching into the next generation. While the ideal of marriage in the region is that it brings two sibling sets together over time (Cannell 1999; Carsten 1997), in these cases it can lead to the estrangement of brothers from sisters, and parents from their children.

I now come to my final set of points. Schooling opportunities and difficulties are distributed unevenly among siblings by age, birth order, and gender, but they also have powerful implications for adulthood and later life. It is, of course, advantageous to enter professions that bring prestige and wealth. Higher earnings can translate into increased authority within the family, at times challenging the age- and birth order-based hierarchy of siblingship, but I found that wealth also leaves one vulnerable to demands for support from kin. The next generation is implicated as well, since advantages and inequalities among parents, uncles, and aunts are passed on and shape relations among cousins (see Cruz, n.d.).

Schooling can lead to migration in pursuit of careers, personal autonomy, and eventually, family life. This can lead to younger, usually female siblings being left behind with the responsibility of caring for aging parents. Alternatively, older siblings with little academic and professional success may be saddled with this responsibility if their younger siblings follow promising careers or leave the family home. Those who stay behind tend to earn 
significantly less money than those who leave, and especially those who travel abroad.

\section{CONCLUSION}

Among those who came of age in the post-1945 central Philippines, edukasyon is conceived as their inheritance from their parents. I have argued that this conception, in addition to signaling schooling's expansion and increased value during this period, reveals how schooling, kinship, and personhood have become absorbed into one another. Schooling was propelled and shaped by relations and what it means to be embedded in them. As anthropologists have emphasized, kinship relations have the potential to effect broader transformations, and the separation of such relations from other domains of social life is erroneous, an illusion of modernity (McKinnon and Cannell 2013). Schooling cannot be reduced to the policies and actions of elites, either colonial or postcolonial (Bryant 2001).

The material I have presented here makes clear that kinship and personhood are marked by plurality. Persons inhabit various relations that, along with their sense of personhood, are underpinned by multiple ideals. Which ideal people invoke is shaped by history, but also depends on their generational location, gender, stage in life, and material circumstances. This plurality has been remarked upon by anthropologists working in diverse settings (Astuti 2000; Carsten 2004; Stafford 2000). In the Philippines, the plurality of ideals is inseparable from its complex colonial past, although it predates the colonizers (Aguilar 1998; Blanc-Szanton 1990; Cannell 1999; Junker 1999).

My account complicates any linear understanding of inheritance and social reproduction (Day 2012). In the context of postwar schooling, the relationship between forebears and their heirs is not unidirectional, but rather involves mutually constitutive flows and exchanges. Parents did not possess what they sought to pass on. Furthermore, in contrast to the conventional emphasis on vertical kinship ties in models of inheritance, here it mediates ties of not only filiation but also siblingship. Personhood here cannot be reduced to a possessive, value-accumulating self that has featured prominently in social theories (Skeggs 2004). That said, I have shown that the relationality of personhood does not imply an absence of personal autonomy, and in fact the realization of edukasyon was predicated on, and amplified, personal autonomy.

Throughout this essay, I have shown how the claim that schooling is an inheritance has a complex relationship with inequalities. On one hand, it reflects moral judgements about the old elite and associated histories of dispossession, indicating how the postwar educated class problematized and sought to overcome inequality. Yet schooling both depended on and generated new forms of inequality within and between families. Here, as in other places, schooling's meanings and consequences are far from obvious and are shaped by broader 
economic and political histories (Froerer and Portisch 2012; Levinson and Holland 1996).

In grappling with the entanglements of schooling, kinship, and personhood, I have accentuated their inextricable links with religious ideas and practices. I have pointed out that kinship cannot be meaningfully isolated from other aspects of social life, including those that conventionally fall under the banner of the "religious," "spiritual," or "cosmological" (Lambek 2013). To be a person is to be related to not only other humans but also a range of nonhuman entities (Das 2015). Schooling itself has spiritual dimensions and its history in the Philippines is intimately connected to that of religious institutions. In the Santa Rosan accounts and experiences I have related here, we see that religion, like kinship and personhood, is marked by plurality and complexity.

Finally, ideals imply pressure, obligation, failure, and judgement, all of which contribute to the ambivalence of kinship (Carsten 2013; Peletz 2001). So, too, do the hierarchies present within kin relations and how they converge with broader social and economic inequalities (McKinnon 2017). Others have remarked on the emotional complexity that marks schooling and journeys of social mobility (e.g., Friedman 2016; Reay 2015). This complexity exists partly because relationships contain within them the potential for enmity and ambivalence. A history of schooling and social mobility must address the history of ambivalence and hierarchies within kinship, how these unfold over time, and how people navigate them.

REFERENCES

Aguilar, Filomeno V. 1998. Clash of Spirits: The History of Power and Sugar Planter Hegemony on a Visayan Island. Honolulu: University of Hawai'i Press.

Aguilar, Filomeno V. with John Estanley Z. Peñalosa, Tania Belen T. Liwanag, Resto S. Cruz I, and Jimmy M. Melendrez. 2009. Maalwang Buhay: Family, Overseas Work, and Cultures of Relatedness in Barangay Paraiso. Quezon City: Ateneo de Manila University Press.

Allerton, Catherine. 2013. Potent Landscapes: Place and Mobility in Eastern Indonesia. Honolulu: University of Hawai'i Press.

Alzona, Encarnacion. 1932. A History of Education in the Philippines 1565-1930. Manila: University of the Philippines Press.

Anderson, Benedict. 1988. Cacique Democracy in the Philippines: Origins and Dreams. New Left Review 169: 3-31.

Anderson, Benedict. 1990. The Idea of Power in Javanese Culture. In Language and Power: Exploring Political Cultures in Indonesia. Ithaca: Cornell University Press, $17-77$.

Anderson-Levitt, Kathryn M. 2005. The Schoolyard Gate: Schooling and Childhood in Global Perspective. Journal of Social History 38, 4: 987-1006.

Astuti, Rita. 2000. Kindreds and Descent Groups: New Perspectives from Madagascar. In Janet Carsten, ed., Cultures of Relatedness: New Approaches to the Study of Kinship. Cambridge: Cambridge University Press, 90-103. 
Atkinson, Will. 2013. A Sketch of 'Family' as a Field: From Realized Category to Space of Struggle. Acta Sociologica 57, 3: 223-35.

Barrows, David P. 1907. Education and Social Progress in the Philippines. Annals of the American Academy of Political and Social Science 30: 69-82.

Bautista, Cynthia. 2001. Composition and Origins of the Philippine Middle Classes. In Michael Hsiao Hsin-Huang, ed., Exploration of the Middle Classes in Southeast Asia. Taipei: Program for Southeast Asian Area Studies, Academia Sinica, 91-149.

Bear, Laura. 2014. Capital and Time: Uncertainty and Qualitative Measures of Inequality. British Journal of Sociology 65, 4: 639-49.

Blanc-Szanton, Cristina. 1990. Collision of Cultures: Historical Reformulations of Gender in the Lowland Visayas, Philippines. In Jane Monnig Atkinson and Shelly Errington, eds., Power and Difference: Gender in Island Southeast Asia. Stanford: Stanford University Press, 345-83.

Bourdieu, Pierre. 1977. Outline of a Theory of Practice. Richard Nice, trans. Cambridge: Cambridge University Press.

Bourdieu, Pierre. 1986. The Forms of Capital. In John G. Richardson, ed., Handbook of Theory and Research for the Sociology of Education. New York: Greenwood Press, 241-58.

Bourdieu, Pierre. 1999. The Contradictions of Inheritance. In The Weight of the World: Social Suffering in Contemporary Society. Stanford: Stanford University Press, 507-13.

Bourdieu, Pierre and Jean-Claude Passeron. 1977. Reproduction in Education, Society and Culture. Richard Nice, trans. London: Sage Publications.

Bryant, Rebecca. 2001. An Aesthetics of Self: Moral Remaking and Cypriot Education. Comparative Studies in Society and History 43, 3: 583-614.

Cannell, Fenella. 1999. Power and Intimacy in the Christian Philippines. Cambridge: Cambridge University Press.

Cannell, Fenella. 2005. Immaterial Culture: "Idolatry" in the Lowland Philippines. In Andrew C. Willford and Kenneth M. George, eds., Spirited Politics: Religion and Public Life in Contemporary Southeast Asia. Ithaca: Southeast Asia Program Publications, Cornell University, 159-84.

Capuno, Joseph J. and Xylee Javier. 2015. Does Poverty Alone Keep Children out of School? The Case of Children under Kinship Care in the Philippines. In Almas Heshmati, Esfandiar Maasoumi, and Guanghua Wan, eds., Poverty Reduction Policies and Practices in Developing Asia. Mandaluyong: Asian Development Bank, 235-53.

Carsten, Janet. 1991. Children in Between: Fostering and the Process of Kinship on Pulau Langkawi, Malaysia. Man (N.S.) 26, 3: 425-43.

Carsten, Janet. 1995. The Substance of Kinship and the Heat of the Hearth: Feeding, Personhood, and Relatedness among Malays in Pulau Langkawi. American Ethnologist 22, 2: 223-41.

Carsten, Janet. 1997. The Heat of the Hearth: The Process of Kinship in a Malay Fishing Village. Oxford: Clarendon Press.

Carsten, Janet. 2004. After Kinship. Cambridge: Cambridge University Press.

Carsten, Janet. 2013. What Kinship Does-and How. HAU: Journal of Ethnographic Theory 3, 2: 245-51.

Claudio, Lisandro E. 2015. Beyond Colonial Miseducation: Internationalism and Deweyan Pedagogy in the American-Era Philippines. Philippine Studies: Historical and Ethnographic Viewpoints 63, 2: 193-220.

Cortes, Josefina R. 1980. The Philippines. In T. Neville Postlethwaite and R. Murray Thomas, eds., Schooling in the ASEAN Region: Primary and Secondary Education in Indonesia, Malaysia, The Philippines, Singapore, and Thailand. Oxford: Pergamon Press, 145-79. 
Cruz, Resto. 2017. Becoming Middle Class: Kinship, Personhood, and Social Mobility in the Central Philippines. PhD thesis, University of Edinburgh.

Cruz, Resto. n.d. Siblingship Beyond Siblings? Cousins and the Shadows of Social Mobility in the Central Philippines (forthcoming).

Das, Veena. 1998. Wittgenstein and Anthropology. Annual Review of Anthropology 27: 171-95.

Das, Veena. 2007. Life and Words: Violence and the Descent into the Ordinary. Berkeley: University of California Press.

Das, Veena. 2015. Affliction: Health, Disease, Poverty. New York: Fordham University Press.

Day, Sophie. 2012. Demographies in Flux. In Richard Fardon et al., eds., The SAGE Handbook of Social Anthropology. Vol. 2. London: SAGE Publications with the Association of Social Anthropologists of the United Kingdom and Commonwealth, 341-53.

Dumont, Jean-Paul. 1993. The Visayan Male "Barkada": Manly Behavior and Male Identity on a Philippine Island. Philippine Studies 41, 4: 401-36.

Edwards, Jeanette and Marilyn Strathern. 2000. Including Our Own. In Janet Carsten, ed., Cultures of Relatedness: New Approaches to the Study of Kinship. Cambridge: Cambridge University Press, 149-66.

Errington, Shelly. 1989. Meaning and Power in a Southeast Asian Realm. Princeton: Princeton University Press.

Errington, Shelly. 1990. Recasting Sex, Gender, and Power: A Theoretical and Regional Overview. In Jane M. Atkinson and Shelly Errington, eds., Power and Difference: Gender in Island Southeast Asia. Stanford: Stanford University Press, 1-58.

Fegan, Brian. 1978. Establishment Fund, Population Increase and Changing Class Structures in Central Luzon. Canberra Anthropology 1, 3: 24-43.

Fox, Frederick W. 1954. Some Notes on Public Elementary Education in Iloilo Province 1885-1899. Philippine Studies 2, 1: 5-19.

Friedman, Sam. 2016. Habitus Clivé and the Emotional Imprint of Social Mobility. Sociological Review 64, 1: 129-47.

Froerer, Peggy and Anna Portisch. 2012. Introduction to the Special Issue: Learning, Livelihoods, and Social Mobility. Anthropology \& Education Quarterly 43, 4: 332-43.

Garcia, Angela. 2014. Regeneration: Love, Drugs and the Remaking of Hispano Inheritance. Social Anthropology 22, 2: 200-12.

Gibson, Thomas. 1994. Childhood, Colonialism and Fieldwork among the Buid of the Philippines and the Konjo of Indonesia. In Jeannine Koubi and Josiane MassardVincent, eds., Enfants et Sociétés d'Asie du Sud-Est. Paris: L'Harmattan, 1-41.

Hage, Ghassan. 2014. Eavesdropping on Bourdieu's Philosophers. In Veena Das, Michael Jackson, Arthur Kleinman, and Bhrigupati Singh, eds., The Ground Between: Anthropologists Engage Philosophy. Durham: Duke University Press, $138-58$.

Hall, Peter Dobkin and George E. Marcus. 1998. Why Should Men Leave Great Fortunes to Their Children? Dynasty and Inheritance in America. In Robert K. Miller, Jr. and Stephen J. McNamee, eds., Inheritance and Wealth in America. New York: Plenum Press, 139-71.

Heiman, Rachel, Mark Liechty, and Carla Freeman. 2012. Introduction: Charting an Anthropology of the Middle Classes. In Rachel Heiman, Carla Freeman, and Mark Liechty, eds., The Global Middle Classes: Theorizing through Ethnography. Santa Fe: SAR Press, 3-29. 
Hollnsteiner, Mary R. 1973. Reciprocity in the Lowland Philippines. In Francis Lynch and Alfonso de Guzman II, eds., Four Readings on Philippine Values. 4th ed. Quezon City: Institute of Philippine Culture, Ateneo de Manila University, 69-91.

Ingold, Tim. 2005. Time, Memory and Property. In Thomas Widlok and Wolde Gossa Tadesse, eds., Property and Equality: Ritualisation, Sharing, Egalitarianism. Oxford: Berghahn Books, 165-74.

Ingold, Tim. 2018. Anthropology and/as Education. Abingdon: Routledge.

Jeffrey, Craig. 2010. Timepass: Youth, Class and the Politics of Waiting in India. Stanford: Stanford University Press.

Jocano, F. Landa. 1969. Growing Up in a Philippine Barrio: Case Studies in Education and Culture. New York: Holt, Rinehart, and Winston.

Johnson, Mark. 1998. At Home and Abroad: Inalienable Wealth, Personal Consumption and Formulations of Femininity in the Southern Philippines. In Daniel Miller, ed., Material Cultures: Why Some Things Matter. London: UCL Press, 215-38.

Junker, Laura L. 1999. Raiding, Trading, and Feasting: The Political Economy of Philippine Chiefdoms. Honolulu: University of Hawai'i Press.

Kajanus, Anni. 2015. Chinese Student Migration, Gender and Family. Basingstoke: Palgrave Macmillan.

Kaufmann, John. 1900. Visayan-English Dictionary (Kapulúñgan Binisayá-Ininglís). Iloilo: La Editorial.

Kaut, Charles. 1961. Utang na Loob: A System of Contractual Obligation among Tagalogs. Southwestern Journal of Anthropology 17, 3: 256-72.

Kipnis, Andrew. 2009. Education and the Governing of Child-Centred Relatedness. In Susanne Brandstädter and Gonçalo D. Santos, eds., Chinese Kinship: Contemporary Anthropological Perspectives. London: Routledge, 204-22.

Knight, Daniel M. 2018. The Desire for Disinheritance in Austerity Greece. Focaal 80: $30-42$.

Kunreuther, Laura. 2009. Between Love and Property: Voice, Sentiment, and Subjectivity in the Reform of Daughter's Inheritance in Nepal. American Ethnologist 36, 3: 545-62.

Lambek, Michael. 2011. Kinship as Gift and Theft: Acts of Succession in Mayotte and Ancient Israel. American Ethnologist 38, 1: 2-16.

Lambek, Michael. 2013. Kinship, Modernity, and the Immodern. In Susan McKinnon and Fenella Cannell, eds., Vital Relations: Modernity and the Persistent Life of Kinship. Santa Fe: SAR Press, 241-60.

Leichter, Howard M. 1975. Political Regime and Public Policy in the Philippines: A Comparison of Bacolod and Iloilo Cities. DeKalb: Center for Southeast Asian Studies, Northern Illinois University.

Leinaweaver, Jessaca B. 2013. Toward an Anthropology of Ingratitude: Notes from Andean Kinship. Comparative Studies in Society and History 55, 3: 554-78.

Levinson, Bradley A. and Dorothy C. Holland. 1996. The Cultural Production of the Educated Person: An Introduction. In Bradley A. Levinson, Douglas E. Foley, and Dorothy C. Holland, eds., The Cultural Production of the Educated Person: Critical Ethnographies of Schooling and Local Practice. Albany: State University of New York Press, 1-54.

Locsin-Nava, Ma. Cecilia. 2001. History and Society in the Novels of Ramon Muzones. Quezon City: Ateneo de Manila University Press.

Magee, Siobhan. 2018. Inheritance. In Hilary Callan, ed., The International Encyclopedia of Anthropology. Vol. 6. Chichester: Wiley-Blackwell, 3260-76.

Magos, Alicia. 1992. The Enduring Ma-Aram Tradition: An Ethnography of a Kinaray-a Village in Antique. Quezon City: New Day Publishers. 
Manuel, E. Arsenio. 1995. Dictionary of Philippine Biography. Vol. 4. Quezon City: Filipiniana Publications.

Margold, Jane A. 1995. Egalitarian Ideals and Exclusionary Practices: U.S. Pedagogy in the Colonial Philippines. Journal of Historical Sociology 8, 4: 375-94.

Martin, Christopher A. 2015. Generations of Migration: Schooling, Youth and Transnationalism in the Philippines. PhD thesis, London School of Economics.

May, Glenn A. 1976. Social Engineering in the Philippines: The Aims and Execution of American Educational Policy, 1900-1913. Philippine Studies 24, 2: 135-83.

Mayblin, Maya and Magnus Course. 2013. The Other Side of Sacrifice: Introduction. Ethnos 79, 3: 307-19.

McCoy, Alfred W. 1982a. A Queen Dies Slowly: The Rise and Decline of Iloilo City. In Alfred W. McCoy and Ed. C. de Jesus, eds., Philippine Social History: Global Trade and Social Transformations. Quezon City: Ateneo de Manila University Press, 297-360.

McCoy, Alfred W. 1982b. Culture and Consciousness in a Philippine City. Philippine Studies 30, 2: 157-203.

McCoy, Alfred W. 2009. Rent-Seeking Families and the Philippine State: A History of the Lopez Family. In Alfred W. McCoy, ed., An Anarchy of Families: State and Family in the Philippines. Repr. Madison: University of Wisconsin Press, 429-536.

McKinley, Robert. 1981. Cain and Abel on the Malay Peninsula. In Mac Marshall, ed., Siblingship in Oceania: Studies in the Meaning of Kin Relations. Lanham: University Press of America, 335-87.

McKinnon, Susan. 2017. Doing and Being: Process, Essence, and Hierarchy in Making Kin. In Simon H. Coleman, Susan B. Hyatt, and Ann Kingsolver, eds., The Routledge Companion to Contemporary Anthropology. London: Routledge, 161-82.

McKinnon, Susan and Fenella Cannell. 2013. The Difference Kinship Makes. In Susan McKinnon and Fenella Cannell, eds., Vital Relations: Modernity and the Persistent Life of Kinship. Santa Fe: SAR Press, 3-38.

Méntrida, Alonso de, comp. 1841. Diccionario de la Lengua Bisaya, Hiligueina y Haraya de la Isla de Panay. Manila: D. Manuel y D. Felis Dayot.

Mrázek, Rudolf. 2010. A Certain Age: Colonial Jakarta through the Memories of Its Intellectuals. Durham: Duke University Press.

Nydegger, William F. and Corrine Nydegger. 1966. Tarong: An Ilocos Barrio in the Philippines. New York: John Wiley \& Sons.

Obendiek, Helena. 2013. When Siblings Determine Your "Fate": Sibling Support and Educational Mobility in Rural Northwest China. In Erdmute Alber, Cati Coe, and Tatjana Thelen, eds., The Anthropology of Sibling Relations: Shared Parentage, Experience, and Exchange. Basingstoke: Palgrave Macmillan, 97-121.

Olwig, Karen Fog and Karen Valentin. 2014. Mobility, Education and Life Trajectories: New and Old Migratory Pathways. Identities: Global Studies in Culture and Power 22, 3: 247-57.

Omohundro, John T. 1981. Chinese Merchant Families in Iloilo: Commerce and Kin in a Central Philippine City. Quezon City: Ateneo de Manila University Press.

Peebles, Gustav. 2010. The Anthropology of Credit and Debt. Annual Review of Anthropology 39: 225-40.

Peletz, Michael G. 2001. Ambivalence in Kinship since the 1940s. In Sarah Franklin and Susan McKinnon, eds., Relative Values: Reconfiguring Kinship Studies. Durham: Duke University Press, 413-44.

Pinches, Michael. 1988. The Working Class Experience of Shame, Inequality, and People Power in Tatalon, Manila. In Benedict J. Kerkvliet and Resil B. Mojares, eds., From Marcos to Aquino: Local Perspectives on Political Transition in the Philippines. Quezon City: Ateneo de Manila University Press, 166-86. 
Pinches, Michael. 1992. The Philippines: The Regional Exception. Pacific Review 5, 4: 390-401.

Ponteras, Moises S. 1980. Folk Healing in Iloilo. PhD thesis, University of the Philippines, Diliman.

Rafael, Vicente L. 1993. Contracting Colonialism: Translation and Christian Conversion in Tagalog Society under Early Spanish Rule. Durham: Duke University Press.

Reay, Diane. 2015. Habitus and the Psychosocial: Bourdieu with Feelings. Cambridge Journal of Education 45, 1: 9-23.

Rosaldo, Michelle Z. 1980. Knowledge and Passion: Ilongot Notions of Self and Social Life. Cambridge: Cambridge University Press.

Sayer, Andrew. 2005. The Moral Significance of Class. Cambridge: Cambridge University Press.

Schrauwers, Albert. 1999. Negotiating Parentage: The Political Economy of 'Kinship' in Central Sulawesi, Indonesia. American Ethnologist 26, 2: 310-23.

Scott, William H. 1994. Barangay: Sixteenth-Century Philippine Culture and Society. Quezon City: Ateneo de Manila University Press.

Skeggs, Beverley. 2004. Exchange, Value and Affect: Bourdieu and the 'Self.' In Lisa Adkins, ed., Feminism after Bourdieu. Oxford: Blackwell, 75-95.

Smith, Robert C. 2006. Mexican New York: Transnational Lives of New Immigrants. Berkeley: University of California Press.

Sonza, Demy P. 1992. Illustrious Ilonggos. Vol. 1. Iloilo City: Iloilo Provincial Historical Committee.

Stafford, Charles. 2000. Chinese Patriliny and Cycles of Yang and Laiwang. In Janet Carsten, ed., Cultures of Relatedness: New Approaches to the Study of Kinship. Cambridge: Cambridge University Press, 37-54.

Stambach, Amy. 2000. Lessons from Mount Kilimanjaro: Schooling, Community, and Gender in East Africa. London: Routledge.

Stambach, Amy. 2006. Revising a Four-Square Model of a Complicated Whole: On the Cultural Politics of Religion and Education. Social Analysis 50, 3: 1-18.

Tiryakian, Edward A. 1958. The Prestige Evaluation of Occupations in an Under Developed Country: The Philippines. American Journal of Sociology 63, 4: 390-99.

Wickberg, Edgar. 1964. The Chinese Mestizo in Philippine History. Journal of Southeast Asian History 5, 1: 62-100.

Wolters, Oliver W. 1999. History, Culture, and Region in Southeast Asian Perspectives. Rev. ed. Ithaca: Cornell Southeast Asia Program, in cooperation with the Institute of Southeast Asian Studies, Singapore.

Wolters, Willem G. 2010. The Development of Property Rights to Land in the Philippines, 1850-1930. In Toon van Meijl and Franz von Benda-Beckmann, eds., Property Rights and Economic Development: Land and Natural Resources in Southeast Asia and Oceania. London: Routledge, 110-38. 
Abstract: This article seeks a deeper understanding of inheritance by examining
how kinship and personhood propel, and are altered by, schooling. It foregrounds
kinship's and personhood's transformative and historical dimensions with an eye
to their complexity and unevenness. The post- 1945 generation in the central Phil-
ippines considers schooling (edukasyon) as their inheritance from their parents,
who had few or no educational credentials themselves. This view reflects edu-
kasyon's increased value after the war, how people both judge and emulate the
old landed elite, and the ongoing salience and elaboration of hierarchical parent-
child ties. Alongside this view, children are recognized as completing, redeeming,
and compensating for their parents. Attainment of edukasyon is seen to require
not only personal striving but also solidarity and sacrifices among siblings.
Yet, edukasyon also fosters autonomy and at times severs kinship ties. Finally,
as an inheritance, edukasyon both depends upon and generates inequality, with
long-term intergenerational implications.

Key words: kinship, personhood, siblingship, parent-child ties, social mobility, schooling, Philippines, inheritance 